\title{
Evaluation of Essential Oils and Their Components for Broad-Spectrum Antifungal Activity and Control of Late Leaf Spot and Crown Rot Diseases in Peanut
}

\author{
G. Krishna Kishore and S. Pande, Department of Pathology, International Crops Research Institute for the Semi- \\ Arid Tropics (ICRISAT), Patancheru 502 324, Andhra Pradesh, India; and S. Harish, Department of Microbiology, \\ Osmania University, Hyderabad 500 007, India
}

\begin{abstract}
Kishore, G. K., Pande, S., and Harish, S. 2007. Evaluation of essential oils and their components for broad-spectrum antifungal activity and control of late leaf spot and crown rot diseases in peanut. Plant Dis. 91:375-379.

Clove oil, cinnamon oil, and five essential oil components (citral, eugenol, geraniol, limonene, and linalool) were tested for growth inhibition of 14 phytopathogenic fungi. Citral completely inhibited the growth of Alternaria alternata, Aspergillus flavus, Curvularia lunata, Fusarium moniliforme, F. pallidoroseum, and Phoma sorghina in paper disc agar diffusion assays. Cinnamon oil, citral, and clove oil as low as $0.01 \%$ (vol/vol) inhibited the spore germination of Cercospora arachidicola, Phaeoisariopsis personata, and Puccinia arachidis by $>90 \%$ in vitro. Limonene and linalool were observed to be the least antifungal against the test fungi and were not used in further studies. Clove oil $(1 \% \mathrm{vol} / \mathrm{vol})$ applied as a foliar spray $10 \mathrm{~min}$ before Phaeoisariopsis personata inoculation reduced the severity of late leaf spot of peanut up to 58\% when challenge inoculated with $10^{4}$ conidia $\mathrm{ml}^{-1}$. This treatment was more effective $(P=0.01)$ than $0.5 \%$ (vol $/ \mathrm{vol})$ citral, cinnamon oil, or clove oil and $1 \%(\mathrm{vol} / \mathrm{vol})$ eugenol or geraniol. Seed treatment with the test compounds had no effect on the incidence of crown rot in peanut in Aspergillus niger-infested soil. However, soil amendment with $0.25 \%$ (vol/wt) clove oil and cinnamon oil reduced the preemergence rotting by 71 and $67 \%$ and postemergence wilting by 58 and $55 \%$, respectively, compared with the nontreated control. These two treatments were more effective $(P<0.01)$ than geraniol on preemergence rotting, and more effective than citral, eugenol, and geraniol on postemergence wilting. All treatments significantly outperformed the nontreated control but none were as effective as thiram treatment.
\end{abstract}

Additional keywords: antimicrobial, groundnut

Synthetic fungicides that combat phytopathogenic fungi can increase crop yields and provide stability of crop production and market quality. However, exponential increase in the use of fungicides has resulted in the development of fungicidetolerant pathogen strains (31) and accumulation of fungicide residues in the food chain above safe limits (11). There is a need for better fungal disease management based on alternatives to synthetic fungicides. Among the various alternatives are plant-derived compounds (17). Essential oils, a group of plant-derived compounds, are a mixture of different terpenoid compounds and their oxygenated derivatives (34). These oils are known for their broadspectrum antifungal activity against both human and plant pathogens $(7,16,24)$. The antifungal essential oils reduce hyphal growth and also induce lysis and cytoplasmic evacuation in fungi (14). Growth

Corresponding author: S. Pande

E-mail: s.pande@cgiar.org

Accepted for publication 6 October 2006.

doi:10.1094/PDIS-91-4-0375

(C) 2007 The American Phytopathological Society inhibition by essential oils often involves induction of changes in cell wall composition (15), plasma membrane disruption, mitochondrial structure disorganization (8), and interference with enzymatic reactions of the mitochondrial membrane, such as respiratory electron transport, proton transport, and coupled phosphorylation steps (19).

Essential oils of Cinnamomum zeylanicum and Syzygium aromaticum (clove) consisting of cinnamaldehyde and eugenol, respectively, as major components (25) are known to be potent antifungal materials $(4,28)$. Citral and geraniol are the major components in essential oils of Cymbopogon citratus (lemongrass) and $C$. martinii (palmarosa), respectively, which are antifungal compounds (26,33). Linalool is a major component in essential oil of Thymus mastichina, with antimicrobial activity (13), and both limonene and linalool are the minor components in essential oils derived from different plants $(2,12,30)$. The majority of these essential oils and their components have proved valuable in protection against postharvest fungal diseases which cause buildup of toxic fungal metabolites in stored foods (17). Few essential oils (for example, oil from seeds of Azadiractha indica) have been shown to be equally effective as chemical fungicides in control of foliar fungal diseases (1).

Late leaf spot caused by Phaeoisariopsis personata (Berk. \& M.A. Curtis) Arx (=Cercosporidium personatum (Berk. \& M.A. Curtis) Deighton) is an important foliar disease of peanut or groundnut (Arachis hypogaea $\mathrm{L}$.). The disease is globally important and can cause yield losses of up to $50 \%$ (22). The soilborne disease crown rot, caused by Aspergillus niger van Tiegham, can cause yield losses of $>10 \%$ (23) and is more prevalent in soils with low moisture content and high temperature (approximately $30^{\circ} \mathrm{C}$ ). In the present study, we evaluated two essential oils and five essential oil components for their broadspectrum antifungal activity against 14 phytopathogenic fungi, including $P$. personata and A. niger. The 14 selected fungi cause significant quantitative and qualitative yield losses of chickpea, peanut, pigeonpea, and sorghum, commonly grown in the semi-arid tropics. Selected essential oils or components were evaluated further for control of late leaf spot and crown rot diseases of peanut following their application as a foliar spray, seed treatment, or soil amendment, with a broader objective of identification of ecofriendly tactics for management of these two diseases.

\section{MATERIALS AND METHODS}

Fungal strains. Single spore isolates of 11 culturable phytopathogenic fungi, $A l$ ternaria alternata, Ascochyta rabiei, Aspergillus niger, A. flavus, Curvularia lunata, Fusarium moniliforme, F. oxysporum f. sp. ciceri, F. pallidoroseum, F. udum, Phoma sorghina, and Rhizoctonia bataticola were obtained from the culture collection of the Department of Pathology, International Crops Research Institute for the Semi-Arid Tropics (ICRISAT), Patancheru, India. Three obligate parasites, Cercospora arachidicola, Phaeoisariopsis Personata, and Puccinia arachidis were harvested from early leaf spot-, late leaf spot-, and rustinfected peanut leaves, respectively, in the farm fields of ICRISAT. Single lesion or pustule isolates of these fungi were multiplied on peanut $\mathrm{cv}$. TMV 2 using the detached leaf technique (32)

Determination of in vitro antifungal activity. Two essential oils (cinnamon oil and clove oil) and five essential oil components (citral, eugenol, geraniol, limonene, and linalool) were purchased from 
Sigma-Aldrich (St. Louis). Antifungal activity of these essential oils and essential oil components against 11 culturable fungi was determined by paper disc agar diffusion assay (3). A spore germination assay (18) was used for evaluating activity of these oils and oil components against the three obligate parasites, which cannot be readily cultured.

Paper disc agar diffusion assay. Autoclaved potato dextrose agar (PDA, 1.5\% agar) was dispensed into 90-mm-diameter petri plates and incubated at room temperature for $24 \mathrm{~h}$. A 5-mm diameter sterilized filter paper disc (Whatman no. 1) was placed at the center of each petri plate and loaded separately with 2 or $4 \mu$ of each of the individual test compounds. Paper discs loaded with sterile distilled water (SDW) in place of a test compound served as controls. After $30 \mathrm{~min}$, the plates were overlaid with a 10-ml suspension of fungal spores in PDA $(0.5 \%$ agar; approximately $10^{4}$ spores $\mathrm{ml}^{-1}$ ) and sealed with Parafilm. Plates inoculated with Ascochyta rabiei were incubated at $20^{\circ} \mathrm{C}$ and all other fungi at $28^{\circ} \mathrm{C}$. The inhibition zone around the paper disc in each treatment was measured in millimeters $72 \mathrm{~h}$ after incubation. Three plates were maintained as replicates of each treatment and the experiment was repeated twice.

Spore germination assay. Fresh spores of $C$. arachidicola, Phaeoisariopsis Personata, and Puccinia arachidis were harvested from sporulating lesions or pustules on peanut leaves using a cyclone spore collector. The spores were suspended in SDW with $0.01 \%$ Tween 20 at $10^{5}$ spores $\mathrm{ml}^{-1}$. The test compounds were diluted to three concentrations $(0.01,0.1$, and $1 \%$ [vol/vol]) with $1 \%$ Tween 20 for uniform distribution of the emulsion, and tested for inhibition of spore germination. The spore suspension and individual test compounds
(50 $\mu \mathrm{l}$ each) were mixed well on a cavity slide, with $1 \%$ Tween 20 as the control. The slides were placed in humid chambers and incubated in the dark at $24 \pm 1^{\circ} \mathrm{C}$. A drop of lactophenol-cotton blue $(40 \mathrm{ml}$ of glycerol, $20 \mathrm{ml}$ of lactic acid, $20 \mathrm{~g}$ of phenol, and $5 \mathrm{ml}$ of $1 \%$ aqueous cotton blue) was added to conidia of $C$. arachidicola and Phaeoisariopsis personata after $24 \mathrm{~h}$, and urediniospores of Puccinia arachidis after $8 \mathrm{~h}$, and spores observed for germination under a microscope. In each treatment, 100 spores were observed and the percent germination inhibition with respect to the control was calculated. The conidia were considered germinated if the length of the germ tube was twice the width of the conidium. The experiment was conducted three times with three replications of each treatment.

Determination of in vivo disease control. Two essential oils, cinnamon oil and clove oil, and three essential oil components, citral, eugenol, and geraniol, were tested for control of late leaf spot and crown rot diseases in peanut in a controlled environment.

Late leaf spot in peanut. Thirty-day-old peanut plants of cv. TMV 2, which are highly susceptible to late leaf spot (9), were used in the experiment. The seedlings were grown in a potting mixture consisting of red alfisol, farm yard manure, and sand $(3: 1: 1)$ in a greenhouse at $28 \pm 3^{\circ} \mathrm{C}$. Plants in $15-\mathrm{cm}$-diameter pots (four per pot) were evenly sprayed with suspensions of essential oils or components in $1 \%$ Tween 20 at concentrations of $0.1,0.5$, and $1 \%$ (vol/vol). Plants treated with $1 \%$ Tween 20 and chlorothalonil (Kavach; Syngenta India Ltd., Mumbai, India) at $2 \mathrm{~g} \mathrm{liter}^{-1}$ served as untreated control and fungicide control, respectively. The test compounds were applied as a prophylactic application at 96,48 , and $24 \mathrm{~h}$ and $10 \mathrm{~min}$ before the pathogen inoculation. The plants were challenge inoculated with conidial suspension of $P$. personata (conidia at $10^{4} \mathrm{ml}^{-1}$ ) in $0.01 \%$ Tween 20 applied as a uniform foliar spray.

Inoculated plants were provided with alternate wet $(16 \mathrm{~h})$ and dry $(8 \mathrm{~h})$ periods of leaf wetness for 8 days after inoculation (DAI) by shifting between the dew chambers and greenhouse at $24 \pm 2^{\circ} \mathrm{C}$. Subsequently, the plants were maintained in a greenhouse at $25 \pm 3^{\circ} \mathrm{C}$. Severity of late leaf spot in different treatments was measured 15 DAI as lesion frequency (i.e., number of lesions per square centimeter of leaf area) using the third quadrifoliate leaf from the top tagged before the inoculation. Two pots of each treatment were considered as one replication and the experiment was conducted three times with three replications of each treatment.

Crown rot in peanut. For evaluation of control of crown rot of peanut, selected compounds were applied as both a seed treatment and soil amendment. Aspergillus niger was multiplied on autoclaved sorghum seed for 8 days at $30^{\circ} \mathrm{C}$. The profusely sporulating culture was mixed with a potting mixture consisting of red alfisol, farm yard manure, and sand $(2: 1: 2)$ at $40 \mathrm{~g}$ $\mathrm{kg}^{-1}$. A. niger-infested potting mixture was filled in the top $6 \mathrm{~cm}$ of the $15-\mathrm{cm}$ diameter pots. The pots were watered and left in the greenhouse for $48 \mathrm{~h}$.

For the seed treatment test, peanut seed (cv. TMV 2) were surface sterilized with $0.02 \% \mathrm{HgCl}_{2}$ and then suspended for 30 min in solutions of either cinnamon oil, citral, clove oil, eugenol, or geraniol. The solutions consisted of each oil or oil component at three different concentrations $(0.1,0.5$, and $1 \%[\mathrm{vol} / \mathrm{vol}])$ with $1 \%$ Tween 20 in water. Eight treated seed were sown in each of the 15 -cm-diameter pots with $A$. niger-infested soil. Peanut seed

Table 1. Antifungal activity of selected essential oils and their components against phytopathogenic fungi, tested by paper disc agar diffusion assay in vitro

\begin{tabular}{|c|c|c|c|c|c|c|c|c|c|c|c|c|}
\hline \multirow[b]{2}{*}{ Treatment $^{b}$} & \multirow[b]{2}{*}{ Conc. $(\mu \mathrm{l})$} & \multicolumn{11}{|c|}{ Diameter of inhibition zone $(\mathbf{m m})^{a}$} \\
\hline & & $\mathbf{A A}$ & $\mathbf{A R}$ & $\mathbf{A N}$ & $\mathbf{A F}$ & CL & FM & FO & FP & FU & PS & RB \\
\hline \multirow[t]{2}{*}{ Cinnamon oil } & 2 & 43.6 & 26 & 33.6 & 36.6 & 47 & 35 & $*$ & 40 & 30 & 54.6 & 17 \\
\hline & 4 & 45 & 37.6 & 41.8 & 40 & 57 & 40 & $*$ & 50.6 & 33.6 & $*$ & 25.6 \\
\hline \multirow{2}{*}{ Citral } & 2 & $*$ & 47.6 & 30.6 & $*$ & $*$ & $*$ & 12.6 & $*$ & 20.6 & $*$ & 12 \\
\hline & 4 & $*$ & $*$ & 35.2 & $*$ & $*$ & $*$ & 23 & * & $*$ & * & $*$ \\
\hline \multirow[t]{2}{*}{ Clove oil } & 2 & 36.6 & 17 & 20 & 19.6 & 36.6 & 25.6 & 13 & 28 & 36 & 46 & 18 \\
\hline & 4 & 46 & 21 & 27.2 & 25 & 43 & 28 & 37 & 39 & 36 & 55 & 23.6 \\
\hline \multirow[t]{2}{*}{ Eugenol } & 2 & 37.6 & 23.6 & 24.4 & 25 & 36.6 & 30 & 17 & 39.6 & 35.6 & 42.6 & 29.6 \\
\hline & 4 & 46.6 & 26.6 & 29.2 & 28.6 & 46.6 & 32.6 & 46.6 & 47 & 36 & 47.6 & 29 \\
\hline \multirow[t]{2}{*}{ Geraniol } & 2 & 42.6 & 24 & 14 & 15.6 & 23 & 21.6 & 9.6 & 15.6 & 18 & 41.6 & 13 \\
\hline & 4 & 34.6 & 28 & 22 & 23 & 31.6 & 19 & 29.6 & 24.6 & 20 & 59 & 16.6 \\
\hline \multirow[t]{2}{*}{ Limonene } & 2 & 0 & 0 & 0 & 0 & 0 & 5 & 0 & 0 & 0 & 0 & 0 \\
\hline & 4 & 0 & 0 & 0 & 0 & 0 & 8 & 0 & 0 & 0 & 0 & 0 \\
\hline \multirow[t]{2}{*}{ Linalool } & 2 & 7.8 & 0 & 0 & 0 & 5.1 & 9 & 0 & 7.6 & 8 & 0 & 0 \\
\hline & 4 & $*$ & 0 & 0 & 0 & $*$ & $*$ & 10 & 10 & 13.6 & 0 & 8.6 \\
\hline \multirow{2}{*}{ Control } & 2 & 0 & 0 & 0 & 0 & 0 & 0 & 0 & 0 & 0 & 0 & 0 \\
\hline & 4 & 0 & 0 & 0 & 0 & 0 & 0 & 0 & 0 & 0 & 0 & 0 \\
\hline $\operatorname{LSD}(P=0.01)$ & $\ldots$ & 3.2 & 2.9 & 2.8 & 2.9 & 3.4 & 2.9 & 2.7 & 3.7 & 2.7 & 4.0 & 2.1 \\
\hline
\end{tabular}

a Values presented are the mean of three repetitions, each with three replications of the experiment; * = no fungal growth was observed in the petri plate. AA $=$ Alternaria alternata, $\mathrm{AR}=$ Ascochyta rabiei, $\mathrm{AN}=$ Aspergillus niger, $\mathrm{AF}=$ A. flavus, $\mathrm{CL}=$ Curvularia lunata, $\mathrm{FM}=F$ usarium moniliforme, $\mathrm{FO}=F$. oxysporum f. sp. ciceri, $\mathrm{FP}=$ F. pallidoroseum, $\mathrm{FU}=$ F. udum, $\mathrm{PS}=$ Phoma sorghina , and $\mathrm{RB}=$ Rhizoctonia bataticola .

${ }^{\mathrm{b}}$ Essential oil or component. LSD $=$ least significant difference (essential oil $\times$ concentration [Conc.]). 
treated with $1 \%$ Tween 20 and thiram at 2 $\mathrm{g} \mathrm{kg}^{-1}$ of seed served as the untreated control and fungicide control, respectively.

For the soil amendment test, $100 \mathrm{ml}$ of a $2.5 \%$ ( $\mathrm{vol} / \mathrm{vol})$ suspension of essential oils or essential oil components in $1 \%$ Tween 20 was thoroughly mixed with $1 \mathrm{~kg}$ of $A$. niger-infested potting mixture and placed in the top $6 \mathrm{~cm}$ of the $15-\mathrm{cm}$-diameter pots $24 \mathrm{~h}$ before planting. Pots mixed with $1 \%$ Tween 20 served as the untreated control. For the fungicide comparison, A. nigerinfested soil was treated with thiram at $2 \mathrm{~g}$ $\mathrm{kg}^{-1}$ of soil. Eight seed were planted in each pot followed by the addition of 200 $\mathrm{ml}$ of SDW. Planted pots for seed treatment and soil amendment tests were maintained in a greenhouse at a temperature of $30 \pm 2^{\circ} \mathrm{C}$ and watered with $100 \mathrm{ml}$ of SDW on alternate days to maintain minimum soil moisture. Incidence of crown rot was measured as preemergence rotting 7 days after sowing (DAS) based on the number of seed germinated (ungerminated seed were considered as rotted) and postemergence wilting 20 DAS based on the number of wilted seedlings with respect to the number of emerged seedlings. The experiment consisted of three replications and was conducted three times.

Data analysis. All the experiments were conducted with three replications per treatment and arranged in a randomized complete block design, and each test was repeated twice. Based on Bartlett's test, it was observed that the data from different repetitions were not significantly different $(P \leq 0.05)$ from each other. Hence, data from individual repetitions were pooled and subjected to analysis of variance (ANOVA) using Genstat 6.0 statistical package (Lawes Agricultural Trust, Rothamsted, UK) to determine the attained level of significance and separate the treatment means.

\section{RESULTS}

Determination of in vitro antifungal activity. Paper disc agar diffusion assay. Cinnamon oil, citral, clove oil, eugenol, and geraniol inhibited the growth of 11 culturable fungi and, generally, greater inhibition was observed with $4 \mu \mathrm{l}$ of test compound rather than $2 \mu$ l (Table 1). Citral was the most effective antifungal compound in the test. It completely inhibited the growth of Alternaria alternata, Aspergillus flavus, Curvularia lunata, F. moniliforme, $F$. pallidoroseum, and Phoma sorghina at a concentration of $2 \mu \mathrm{disc}^{-1}$. $F$. oxysporum and $R$. bataticola were the least sensitive to citral at the same concentration. Limonene was the least effective among all the test compounds, and was slightly inhibitory only to $F$. moniliforme. The antifungal activity of linalool was fungus specific, because it completely inhibited the growth of Alternaria alternata, $C$. lunata, and $F$. moniliforme while being ineffective against Ascochyta rabiei,
Aspergillus niger, A. flavus, and Phoma sorghina at a concentration of $4 \mu \mathrm{ldisc}{ }^{-1}$ (Table 1).

Spore germination assay. For all control treatments, which contained only $1 \%$ Tween 20 in SDW, conidial germination was $>90 \%$. Cinnamon oil, citral, clove oil, and eugenol at 1 and $0.1 \%$ concentrations and geraniol at $1 \%$ concentration completely inhibited the in vitro germination of spores of Cercospora arachidicola, Phaeoisariopsis personata, and Puccinia arachidis (Fig. 1). Cinnamon oil, citral, and clove oil at $0.01 \%(\mathrm{vol} / \mathrm{vol})$ inhibited $>90 \%$

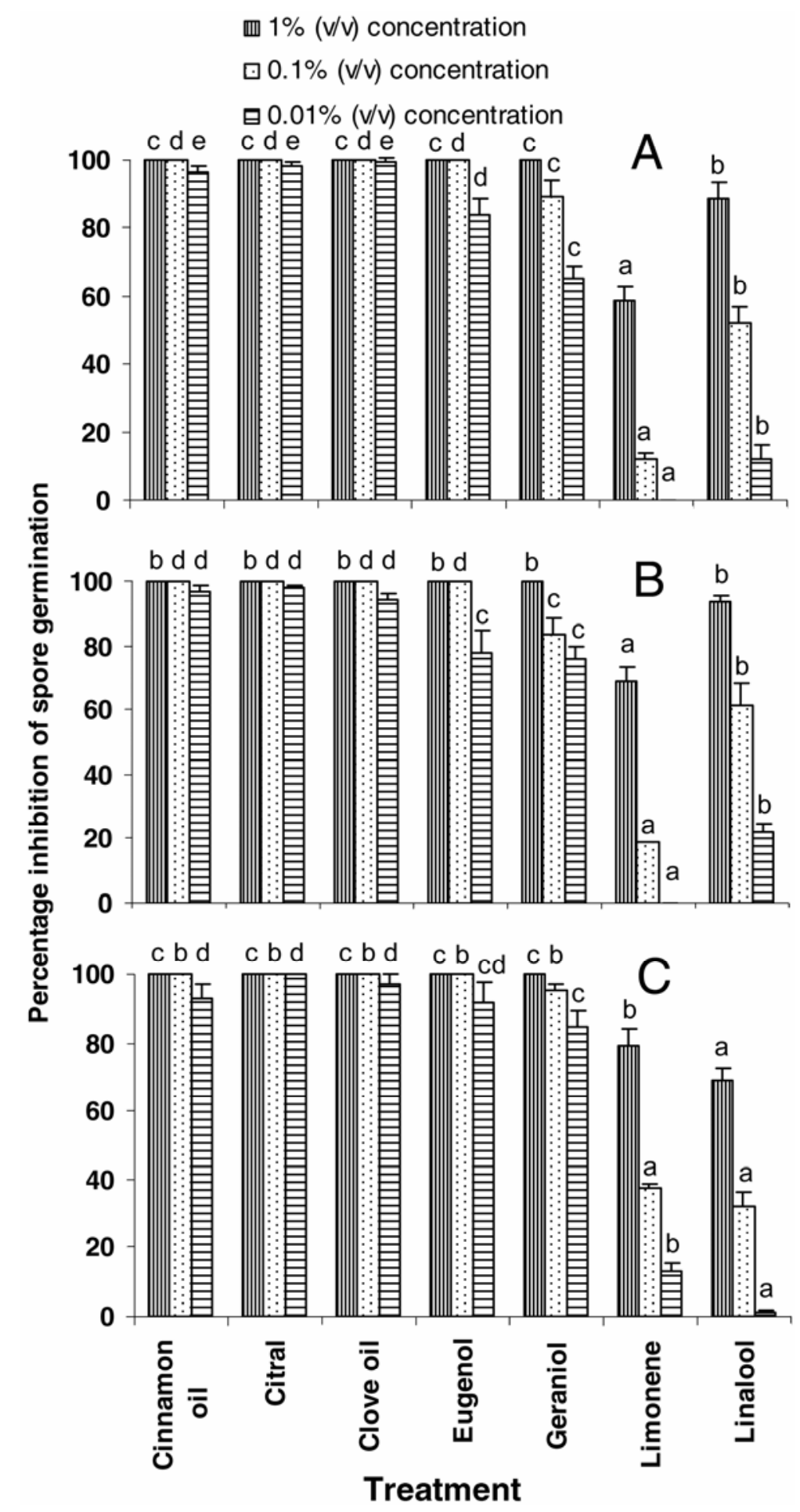

Fig. 1. In vitro antifungal activity of essential oils and their components against obligate phytoparasitic fungi A, Cercospora arachidicola, B, Phaeoisariopsis personata, and $\mathbf{C}$, Puccinia arachidis tested by spore germination assay. Germination of conidia of $C$. arachidicola and Phaeoisariopsis personata was recorded $24 \mathrm{~h}$ after incubation, and urediniospores of Puccinia arachidis $8 \mathrm{~h}$ after incubation. The percent inhibition of conidial or urediniospore germination was calculated with respect to germination in water control, and the values are the mean of three repetitions, each with three replications of the experiment. The horizontal bars above each bar represent the standard error of mean. Individual bars in each series represented by the same letter do not differ significantly at $P=0.01$. 
of spore germination for the three fungi. Limonene was the least effective compound against germination of $C$. arachidicola and Phaeoisariopsis personata, and linalool was least effective against Puccinia arachidis spore germination (Fig. 1).

Determination of in vivo disease control. Late leaf spot in peanut. The essential oils and essential oil components applied as a prophylactic spray at 96,48 , and $24 \mathrm{~h}$ before the pathogen inoculation had lesion frequencies similar to the unprotected control (data not shown). The essential oil or components applied $10 \mathrm{~min}$ before pathogen inoculation significantly $(P<$ 0.001 ) reduced the lesion frequency compared with the untreated control (Table 2). Lesion frequency was minimum with $1 \%$ (vol/vol) clove oil treatment $(58 \%$ less compared with the untreated control) but similar to that with cinnamon oil and citral at $1 \%$. Clove and cinnamon oils at $1 \%$ were significantly $(P=0.01)$ more effective than $0.5 \%(\mathrm{vol} / \mathrm{vol})$ clove oil or either rate of geraniol or eugenol. However, lesion frequency with clove oil at $0.5 \%$ (vol/vol) concentration did not differ from other essential oil treatments. Treatment with chlorothalonil was more effective than any of the essential oil treatments because there was no lesion development with this treatment.

Crown rot in peanut. Seed treatment with selected essential oils or components at the three concentrations of $0.1,0.5$, and $1 \%(\mathrm{vol} / \mathrm{vol})$ had no significant $(P=0.05)$ effect on incidence of preemergence and postemergence infection by Aspergillus niger in peanut seedlings (data not shown). Seed treatment with the chemical fungicide thiram reduced both the preemergence rotting and postemergence wilting by approximately $75 \%$.

Soil amendment with cinnamon oil, citral, clove oil, eugenol, and geraniol at

Table 2. Effect of essential oils and their components, applied as prophylactic sprays $10 \mathrm{~min}$ prior to inoculation, on the severity of late leaf spot in peanut ${ }^{\mathrm{a}}$

\begin{tabular}{lcc}
\hline Treatment & $\begin{array}{c}\text { Conc. } \\
(\%)\end{array}$ & $\begin{array}{c}\text { Lesion } \\
\text { frequency }\end{array}$ \\
\hline Cinnamon oil & 0.5 & 1.2 \\
& 1.0 & 0.9 \\
Citral & 0.5 & 1.2 \\
& 1.0 & 1.0 \\
Clove oil & 0.5 & 1.1 \\
& 1.0 & 0.8 \\
Eugenol & 0.5 & 1.3 \\
& 1.0 & 1.2 \\
Geraniol & 0.5 & 1.3 \\
& 1.0 & 1.2 \\
Chlorothaolonil & 0.2 & 0.0 \\
Water control & $\ldots$ & 1.9 \\
LSD $(P=0.01)$ & $\ldots$ & 0.21 \\
\hline a Conc. = concentration (percent vol/vol or \\
wt/vol), lesion frequency data are the number \\
of lesions per square centimeter of leaf area \\
and are the mean of three repetitions, each \\
with three replications of the experiment, and \\
LSD = least significant difference.
\end{tabular}

$0.25 \%$ (vol/wt) significantly $(P<0.001)$ reduced the preemergence rotting in peanut seedlings, compared with the untreated control (Fig. 2). Soil amendment with clove oil and cinnamon oil were the most effective treatments for reducing preemergence rotting. For these two treatments, the postemergence wilting was reduced by 58 and $55 \%$, respectively, compared with the untreated control. Also, these two treatments were more effective in reducing postemergence wilting $(P=0.01)$ than citral, eugenol, and geraniol. Soil treatment with citral, eugenol, and geraniol reduced preemergence rotting by 62,58 , and $54 \%$ and postemergence wilting by 38,17 , and $14 \%$, respectively. Soil amendment of thiram reduced the preemergence rotting by $90 \%$ and postemergence wilting by $70 \%$.

\section{DISCUSSION}

Plant-derived compounds as crop protectants represent a vast and rapidly progressing resource. Essential oils are a rich source of broad-spectrum antifungal plantderived metabolites that inhibit both fungal growth and production of toxic metabolites (17). This study evaluated the broadspectrum antifungal activity of selected essential oils and their components and their use as fungicides for management of fungal diseases of peanut. Compounds with broad-spectrum activity are expected to provide protection against a range of pathogenic fungi that attack the plant at the same or subsequent growth stages following their application. The essential oils and essential oil components selected for this study are known for antifungal activity and also are commercially available. A paper disc agar diffusion assay was selected to evaluate the antifungal activity of test compounds against culturable fungi. This assay method provides qualitative information on the efficacy of test compounds and is used routinely in such studies $(10,20)$. We observed large inhibition zones in the paper disc agar diffusion assay which established the antifungal activity of the essential oils and essential oil components.

Cinnamon oil, clove oil, and the essential oil components citral, eugenol, and geraniol were found to have broadspectrum antifungal activity and inhibited 14 phytopathogenic fungi tested in the disc diffusion assay or spore germination assay. The fungi used in the present study represented pathogens of many different hosts, each of which cause significant economic losses in agricultural yields worldwide. The above-mentioned oil compounds are known to be antifungal against one or more of the test fungi in different research studies $(17,21,29)$. However, the current study provides comparative information on the activity spectrum of these compounds against selected agriculturally important fungi under similar test conditions.

In a controlled environment, all the essential oils and essential oil components tested were ineffective against late leaf spot in vivo when applied at least $24 \mathrm{~h}$ before pathogen inoculation. The ineffectiveness of essential oils in reducing the severity of the foliar disease could be due

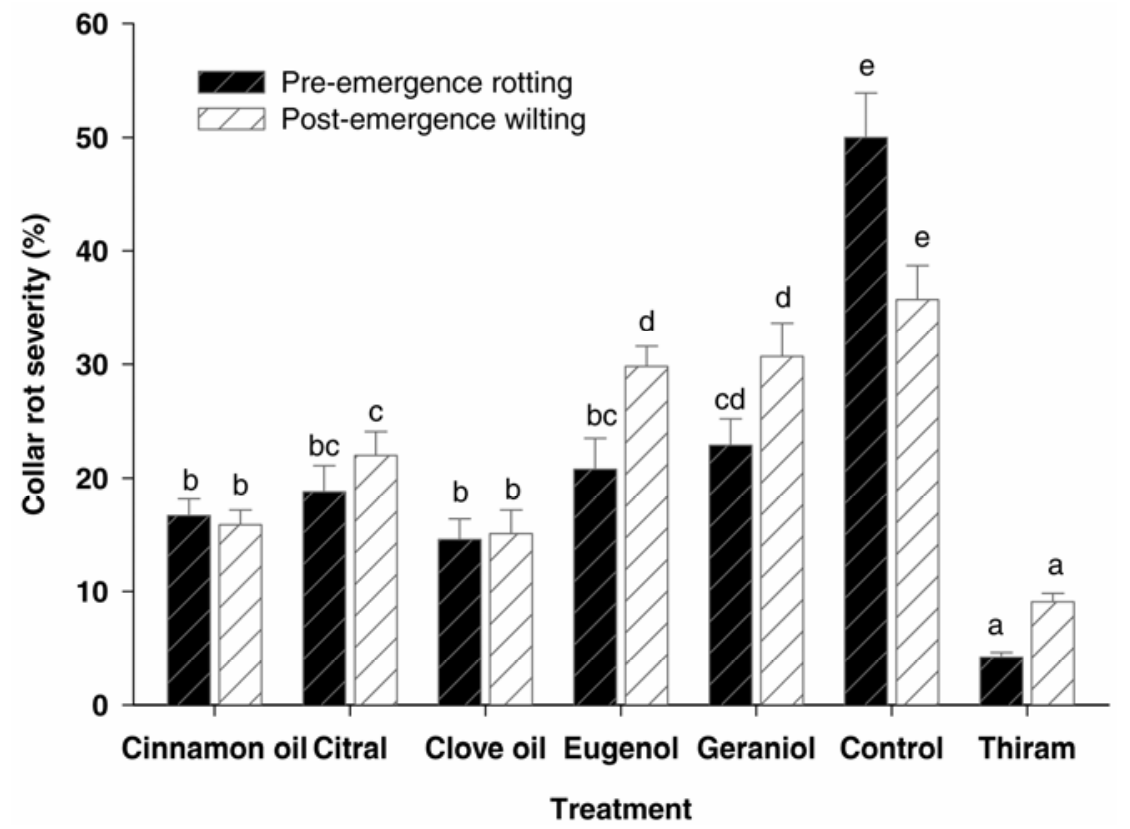

Fig. 2. Effect of soil amendment with essential oils and their components on the severity of crown rot in peanut seedlings. Aspergillus niger-infested potting mixture was treated with essential oils or essential oil components at $0.25 \%$ (vol/wt) $24 \mathrm{~h}$ before planting. Preemergence rotting and postemergence wilting caused by A. niger was measured in different treatments at 7 and 20 days after sowing, respectively. Disease incidence values are the mean of three repetitions, each with three replications of the experiment. The horizontal bars above each bar represent the standard error of mean. Individual bars in each series represented by the same letter do not differ significantly at $P=0.01$. 
largely to the volatile nature of essential oils. It is known that germination and penetration of Phaeoisariopsis personata conidia on the leaf surface of peanut $\mathrm{cv}$. TMV 2 requires 24 to $72 \mathrm{~h}$ (27). The majority of the essential oils are more fungistatic than fungicidal (17) and, thus, their persistence on the phylloplane determines their in vivo efficacy. Our results indicate that it is impractical to use essential oils as foliar sprays for control of late leaf spot.

There have been limited reports on the potential role of essential oils and essential components as protectants against soilborne fungi when applied as seed treatment (17). However, all the essential oils and essential oil components applied as seed treatment failed to protect peanut from A. niger infection. In contrast, soil amendment with selected essential oils and essential oil components effectively reduced the incidence of both preemergence rotting and postemergence wilting of peanut seedlings in A. niger- infested soil. Cinnamon oil and clove oil were more effective than the essential oil components in control of postemergence wilting. Decrease in plant disease incidence through reduction in soil fungal populations with use of oils has been reported. Bowers and Lock (6), for example, reported that treatment with 5 and $10 \%$ clove oil and synthetic cinnamon oil reduced soil populations of Phytophthora nicotianae by $98 \%$ after 21 days compared with unprotected soil. Clove oil also reduced the population density of $F$. $o x$ ysporum f. sp. chrysanthimi by $97.5 \%$, measured 3 days after treatment (5).

The broad-spectrum antifungal essential oils and their components tested in the present study do not hold promise for control of late leaf spot and crown rot diseases of peanut. The essential oils applied as a prophylactic foliar spray were not effective against late leaf spot in controlled environment tests. Although soil amendment with essential oils did show some effectiveness in control of crown rot, application of higher concentrations of these compounds may be needed but is impractical in field conditions.

\section{LITERATURE CITED}

1. Amadioha, A. C. 2000. Controlling rice blast in vitro and in vivo with extracts of Azadirachta indica. Crop Prot. 19:287-290.

2. Bahl, J. R., Garg, S. N., Singh, S. C., Bansal, R. P., Nagvi, A. A., and Kumar, S. 2000. Composition of linalool rich essential oil from Lippia alba grown in Indian plains. Flavour Fragr. J. 15:199-200.

3. Bauer, A. W., Kirby, W. M. M., Sherries, J. C., and Turck, M. 1966. Antibiotic susceptibility testing by a standardized single disk method. Am. J. Clin. Pathol. 45:493-496.

4. Beg, A. Z., and Ahmad, I. 2002. In vitro fungitoxicity of the essential oil of Syzygium aro- maticum. World J. Microbiol. Biotechnol. 18:317-319.

5. Bowers, J. H., and Locke, J. C. 2000. Effects of botanical extracts on the population density of Fusarium oxysporum in soil and control of Fusarium wilt in the greenhouse. Plant Dis. 84:300-305.

6. Bowers, J. H., and Locke, J. C. 2004. Effect of formulated plant extracts and oils on population density of Phytophthora nicotianae in soil and control of Phytophthora blight in the greenhouse. Plant Dis. 88:11-16.

7. Daferera, D. J., Ziogas, B. N., and Polission, M. G. 2003. The effectiveness of plant essential oils on the growth of Botrytis cinerea, Fusarium sp. and Clavibacter michiganensis subsp. michiganensis. Crop Prot. 22:39-44.

8. de Billerbeck, V. G., Roques, C. G., Bessiere, J. M., Fonvieille, J. L., and Dargent, R. 2001. Effects of Cymbopogon nardus (L.) W. Watson essential oil on the growth and morphogenesis of Aspergillus niger. Can. J. Microbiol. 47:917.

9. Dwivedi, S. L., Pande, S., Rao, J. N., and Nigam, S. N. 2002. Components of resistance to late leaf spot and rust among interspecific derivatives and their significance in a foliar disease resistance breeding in groundnut ( $\mathrm{Ara}$ chis hypogaea L.). Euphytica 125:81-88.

10. Elgayyar, M., Draughon, F. A., Golden, D. A., and Mount, J. R. 2001. Antimicrobial activity of essential oils from plants against selected pathogenic and saprophytic microorganisms. J. Food Prot. 64:1019-1024.

11. El-Nahhal, Y. 2004. Contamination and safety status of plant food in Arab countries. J. Appl. Sci. 4:411-417.

12. El-Sakhawy, F. S., El-Tantawy, M. E., Ross, S. A., and El-Sholy, M. A. 1998. Composition and antimicrobial activity of the essential oil of Murraya exotica L. Flavour Fragr. J. 13:59-62.

13. Faleiro, M. L., Miguel, M. G., Ladeiro, F., Venancio, F., Ravares, R., Brito, J. C., Figueiredo, A. C., Barroso, J. G., and Pedro, L. G. 2003. Antimicrobial activity of essential oils isolated from Portuguese endemic species of Thymus. Lett. Appl. Microbiol. 36:35-40.

14. Fiori, A. C. G., Schwan-Estrada, K. R. F., Stangarlin, J. R., Vida, J. B., Scapim, C. A., Cruz, M. E. S., and Pascholti, S. F. 2000. Antifungal activity of leaf extracts and essential oils of some medicinal plants against Didymella bryoniae. J. Phytopathol. 148:483-487.

15. Ghfir, B., Fonvieille, J. L., and Dargent, R. 1997. Influence of essential oil of Hyssopus officinalis on the chemical composition of the walls of Aspergillus fumigatus (Fresenius). Mycopathologia 138:7-12.

16. Isman, B. M. 2000. Plant essential oils for pest and disease management. Crop Prot. 19:603608.

17. Kishore, G. K, and Pande, S. 2004. Natural fungicides for management of phytopathogenic fungi. Annu. Rev. Plant Pathol. 3:331-356.

18. Kishore, G. K., Pande, S., and Podile, A. R. 2005. Biological control of collar rot disease with broad-spectrum antifungal bacteria associated with groundnut. Can. J. Microbiol. 51:123-132.

19. Knobloch, K., Pauli, A., Iberl, B., Weis, N., and Weigand H. 1989. Antibacterial activity and antifungal properties of essential oil components. J. Essent. Oil Res. 1:119-128.

20. Lahariya, A. K., and Rao, J. T. 1979. In vitro antimicrobial studies of the essential oils of Cyprus scariosus and Ocimum basilicum. In- dian Drug. 4:150-152.

21. Mahmoud, A. L. 1994. Antifungal action and antiaflatoxigenic properties of some essential oil constituents. Lett. Appl. Microbiol. 19:110113.

22. McDonald, D., Subrahmanyam, P., Gibbons, R. W., and Smith, D. H. 1985. Early and late leaf spots of groundnut. Inf. Bull. no. 21. International Crops Research Institute for the Semi-Arid Tropics, Patancheru 502 324, India.

23. Pande, S., and Rao, J. N. 2000. Changing scenario of groundnut diseases in Andhra Pradesh, Karnataka and Tamil Nadu states of India. Int. Arachis Newslett. 20:42-44.

24. Pandey, A. K., Rai, M. K., and Acharya, D. 2003. Chemical composition and antimycotic activity of the essential oils of corn mint (Mentha arvensis) and lemon grass (Cymbopogon flexuosus) against human pathogenic fungi. Pharm. Biol. 41:421-425.

25. Paranagama, P. A. 1991. Analysis of Sri Lankan essential oils by gas chromatography and mass spectroscopy. ITI, Colombo, Sri Lanka.

26. Paranagama, P. A., Abeysekera, K. H. T. Abeywickrama, K., and Nugaliyadde, L. 2003. Fungicidal and anti-aflatoxigenic effects of the essential oil of Cymbopogon citratus (DC.) Stapf. (lemongrass) against Aspergillus flavus Link. isolated from stored rice. Lett. Appl. Microbiol. 37:86-90.

27. Rajesh, T. R. 1998. Histopathology of Phaeoisariopsis personata infection and effect of temperature, relative humidity, plant age and inoculum concentration on the components of resistance to late leaf spot in groundnut (Arachis hypogaea L.). M.Sc. thesis, Acharya NG Ranga Agricultural University, Rajendranagar, Hyderabad, Andhra Pradesh, India.

28. Ranasinghe, L., Jayawardena, B., and Abeywickrama, K. 2002. Fungicidal activity of essential oils of Cinnamomum zeylanicum (L.) and Syzygium aromaticum (L.) Merr et L. M Perry against crown rot and anthracnose pathogens isolated from banana. Lett. Appl. Microbiol. 35:208-211.

29. Saikia, D., Khanuja, S. P. S., Kahol, A. P. Gupta, S. C., and Kumar, S. 2001. Comparative antifungal activity of essential oils and constituents from three distinct genotypes of Cymbopogon spp. Curr. Sci. 80:1264-1266.

30. Senatore, F., and deFeo, V. 1999. Chemical composition of the essential oil from Tagetus mandonii Sch. Bip. Flavour Fragr. J. 14:32-34.

31. Staub, T. 1991. Fungicide resistance: practical experience with antiresistance strategies and the role of integrated use. Annu. Rev. Phytopathol. 29:421-442.

32. Subrahmanyam, P., Mc Donald, D., and Rao, P. V. S. 1983. Influence of host genotype on uredospore production and germinability in Puccinia arachidis. Phytopathology 73:726729.

33. Velluti, A., Sanchis, V., Ramos, A. J., Turon, C., and Marin, S. 2004. Impact of essential oils on growth rate, zearalenone and deoxynivalenol production by Fusarium graminearum under different temperature and water activity conditions in maize grain. J. Appl. Microbiol. 96:716-724

34. Wijesekara, R. O. B., Ratnatunga, C. M., and Durbeck, K. 1997. The Distillation of Essential Oils. Manufacturing and Plant Construction Handbook. Protrade, Department of Foodstuffs \& Agricultural Products, Eschborn, Federal Republic of Germany. 